\title{
Multiple factors influence the contribution of individual immunoglobulin light chain genes to the naïve antibody repertoire
}

\author{
Sean P Fitzsimmons, Antonina G Aydanian, Kathleen J Clark and Marjorie A Shapiro*
}

\begin{abstract}
Background: The naive antibody repertoire is initially dependent upon the number of germline V(D)J genes and the ability of recombined heavy and light chains to pair. Individual VH and VL genes are not equally represented in naïve mature B cells, suggesting that positive and negative selection also shape the antibody repertoire. Among the three member murine $V_{K} 10 \mathrm{~L}$ chain family, the $V_{K} 10 C$ gene is under-represented in the antibody repertoire. Although it is structurally functional and accessible to both transcriptional and recombination machinery, the Vk10C promoter is inefficient in pre-B cell lines and productive $V_{k} 10 C$ rearrangements are lost as development progresses from pre-B cells through mature $B$ cells. This study examined VHNK10 pairing, promoter mutations, VK10 transcript levels and receptor editing as possible factors that are responsible for loss of productive $V_{k} 10 C$ rearrangements in developing B cells.

Results: We demonstrate that the loss of $V_{k} 10 C$ expression is not due to an inability to pair with $\mathrm{H}$ chains, but is likely due to a combination of other factors. Levels of mRNA are low in sorted pre-B cells and undetectable in B cells. Mutation of a single base in the three prime region of the $V_{K} 10 C$ promoter increases $V_{K} 10 C$ promoter function in pre-B cell lines. Pre-B and $B$ cells harbor disproportionate levels of receptor-edited productive $V_{k} 10 C$ rearrangements.

Conclusions: Our findings suggest that the weak $V_{k} 10 C$ promoter initially limits the amount of available $V_{k} 10 C L$ chain for pairing with $\mathrm{H}$ chains, resulting in sub-threshold levels of cell surface B cell receptors, insufficient tonic signaling and

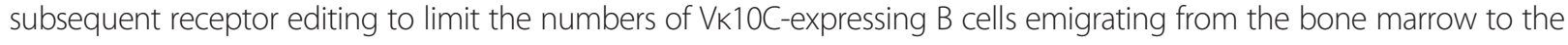
periphery.
\end{abstract}

Keywords: B lymphocytes, Antibodies, Generation of diversity, Receptor editing, Rodent, Tonic signaling

\section{Background}

The potential diversity of the naïve antibody repertoire is dependent in part upon the number of functional $\mathrm{VH}$ and VL genes that are able to undergo successful V(D)J recombination and $\mathrm{H}-\mathrm{L}$ chain pairing, followed by the selection events that occur during B cell development. The murine Ig kappa locus spans over $3 \mathrm{Mb}$ on chromosome six and is composed of approximately $140 \mathrm{VK}$ genes that reside in the large five-prime end of the locus, four $\mathrm{J} \kappa$ genes, a kappa constant region gene and three enhancers [1-6]. Of the 140 murine VK genes that have been mapped and sequenced [7-9], 95 are considered to be potentially

\footnotetext{
* Correspondence: marjorie.shapiro@fda.hhs.gov

Laboratory of Molecular and Developmental Immunology, Division of Monoclonal Antibodies, OBP, CDER, FDA, 10903 New Hampshire Avenue, Silver Spring, MD 20993, USA
}

functional while 45 are considered to be defective due to mutations in promoters, splice sites, recombination signal sequences, the presence of stop codons or frame shifts, and the replacement of invariant amino acids. VK genes can be in either the same or opposite transcriptional orientation relative to the JK genes, with recombination resulting in either a deletion or inversion of the intervening sequences. The frequency of $\mathrm{VK}$ gene usage does not exhibit positional bias in early development and usage in adults does not correlate with the size of a given $\mathrm{VK}_{\mathrm{K}}$ family [10-14]. Approximately 40\% of $V_{\kappa}$ genes are in the opposite transcriptional orientation relative to JK and rearrange by inversion, which may affect the overall usage pattern of particular $V_{\kappa}$ genes. Utilization of individual VK genes in splenic $B$ cell cDNA libraries from BALB/c mice and in $V k$ cDNA transcripts from $B$ cells of bone marrow, spleen and 
lymph node of C57BL/6 mice have been shown to range from $0.001 \%$ to $12.5 \%[15,16]$ with skewing of the repertoire towards a limited set of $\mathrm{VK}_{\mathrm{K}}$ genes and families. In one study, skewing of the repertoire by preferred $\mathrm{VK}_{\mathrm{K}} \mathrm{JK}$ rearrangements was such that seven $V_{K}$ genes represented greater than $40 \%$ of the repertoire in C57BL/6 mice [16]. It is not known why other potentially functional $\mathrm{Vk}$ genes would be underutilized, but it was hypothesized that the observed preferential $V_{\kappa}$ gene usage could be the result of intrinsic rearrangement preferences and/or differences in expression levels.

Factors that have the potential to affect the inclusion of a $\mathrm{V}$ region gene in the available repertoire include changes in nuclear organization [17-19] and subsequent changes in accessibility of the Ig loci to the transcription and recombination machinery [20-29], recombination efficiency due to differences in the sequences of the recombination signal sequence (RSS) [30-32], promoter efficiency [33-35] receptor editing [36] and the ability of $\mathrm{H}$ and L-chains to pair $[37,38]$.

We have utilized the murine Vk10 family of immunoglobulin light chain genes to examine multiple factors that can influence a VK gene's contribution to the antibody repertoire. The Vk10 family contains three structurally functional members, Vк10A (IMGT IGKV10-96), Vк10B (IMGT IGKV10-94) and Vk10C (IMGT IGKV10-95) that share greater than $94 \%$ nucleic acid and 91\% amino acid homology. Vк10A and B are expressed in antibody responses to a wide variety of both $\mathrm{T}$-dependent and $\mathrm{T}$-independent antigens, while $\mathrm{V} \kappa 10 \mathrm{C}$ has never been detected as part of a functional antibody. Furthermore, $\mathrm{V \kappa} 10 \mathrm{C}$ mRNA is present at low levels in bone marrow, spleen and lymph nodes $[16,39,40]$. Our previous studies of the Vk10 family have shown that all Vk10 genes are accessible as measured by levels of sterile transcripts and not impaired in their ability to rearrange in pre-B cells. The promoter for $\mathrm{V} \kappa 10 \mathrm{C}$ was less efficient than the $\mathrm{V} \kappa 10 \mathrm{~A}$ promoter in pre-B cell lines but worked equally as well as the $\mathrm{V} \kappa 10 \mathrm{~A}$ promoter in immature, mature and plasma cell lines. The frequency of cells carrying productive $\mathrm{Vk} 10 \mathrm{C}$ rearrangements are lost as pre-B cells develop into immature $\operatorname{IgM}^{+}$cells in the bone marrow and through the transition to mature $\mathrm{B}$ cells in the spleen. Impaired $\mathrm{VH}$ and $\mathrm{VL}$ pairing and poor transcription of $\mathrm{V} \kappa 10 \mathrm{C}$ may lead to reduced BCR expression and insufficient tonic signaling, which may cause the loss of $\mathrm{V} \kappa 10 \mathrm{C}$ productive rearrangements by receptor editing. Additionally, negative selection of B cells bearing Vк10C light chains would likewise trigger receptor editing and result in loss of productive Vk10C alleles.

In the current study, we compared levels of $\mathrm{V} \kappa 10$ transcripts in pre-B and splenic B cells to known promoter activities in transient transfection assays and examined the
VК10C promoter using site specific mutagenesis to identify sites responsible for promoter inefficiency. The ability of Vk10C L chains to pair with $\mathrm{H}$ chains was examined using phage display and receptor editing was assessed by quantifying displacement of Vk10 productive rearrangements by secondary $\mathrm{V} \kappa \mathrm{J} \kappa$ rearrangements or recombining sequence (RS) editing events. Our results suggest that a combination factors result in the underutilization of the Vk10C gene in the naïve antibody repertoire.

\section{Methods}

\section{Ethics statement}

BALB/cAnCr mice were purchased from the National Cancer Institute, Division of Cancer Treatment, Frederick, MD. Mice were maintained and experiments were performed in accordance with the Center for Biologics Evaluation and Research Animal Care and Use Committee regulations under protocol WO-2012-60.

\section{Pre-B cell sorting and CDNA synthesis}

Bone marrow was collected from femurs of 12-16 week old male and female BALB/cAnNCr mice (National Cancer Institute, Division of Cancer Treatment, Frederick, MD). Red cells were lysed with ACK lysis buffer for 3 min on ice, and the remaining cells were washed in PBS and resuspended at $2 \times 10^{7}$ cells $/ \mathrm{ml}$ in FACS buffer. Cells were stained with PE-anti-B220 (BD Pharmingen, San Diego, CA), FITC anti-mouse IgM (BD Pharmingen) and biotin anti-CD43 (BD Pharmingen) for $30 \mathrm{~min}$ on ice. After two washes, cells were stained with streptavidin-PE (Molecular Probes, Eugene, OR) for $30 \mathrm{~min}$ on ice. Cells were resuspended at a concentration of $1.5 \times 10^{7}$ cells $/ \mathrm{ml}$ and sorted on a Becton Dickinson FAC-Star ${ }^{\text {Plus }}$ for $\mathrm{IgM}^{-} / \mathrm{B} 220^{+} / \mathrm{CD} 43^{-}$pre-B cells. Seven individual sorts were performed, each with cells from 3-4 mice. Two micrograms $(\mu \mathrm{g})$ of RNA purified from the pre-B cells using the Trizol method (Life Technologies, Carlsbad, CA) was used to synthesize cDNA using the Omniscript (Qiagen, Venlo, Netherlands) protocol with either oligo $\mathrm{dT}$ or the gene-specific CK73 primer (5'-cctgttgaagctctt gacaatgggtg-3'), which binds near the 3 ' end of the kappa constant region. One tenth $(2 \mu \mathrm{l})$ of each cDNA reaction was used for each Vk10A, B or C quantitative PCR (qPCR) reactions as described below.

\section{Vк10 qPCR in pre-B cells and spleen}

$\mathrm{V \kappa} 10 \mathrm{~A}, \mathrm{~B}$ and $\mathrm{C}$ qPCR standard templates were made by PCR using total BALB/c spleen cDNA. RNA was made from $5 \times 10^{6} \mathrm{BALB} / \mathrm{c}$ spleen cells using the Trizol method and cDNA was synthesized using the Omniscript protocol and an oligo dT primer. Primers for amplification of $\mathrm{V} \kappa 10$ standards include the gen 11 primer (5'-tcctcctgtctgcctctctggg- $\left.3^{\prime}\right)$, which resides in framework 1 and is identical in all three Vк10 genes, 
and the CK73 primer which anneals to the kappa constant region. One tenth $(2 \mu \mathrm{l})$ of the spleen cDNA was PCR-amplified in a $100 \mu \mathrm{l}$ reaction containing $1.5 \mathrm{mM}$ $\mathrm{MgCl}_{2}, 0.05 \mathrm{mM}$ dNTP's, and $50 \mathrm{pmol}$ of each primer. PCR reaction conditions consisted of $95^{\circ} \mathrm{C}$ for $4 \mathrm{~min}, 95^{\circ} \mathrm{C}$ for $1 \mathrm{~min} / 72^{\circ} \mathrm{C}$ for $2 \mathrm{~min}$ (30 cycles), $72^{\circ} \mathrm{C}$ for $10 \mathrm{~min}$, and a $4^{\circ} \mathrm{C}$ hold. PCR products were ligated into the pCR 4.0 TOPO vector (Life Technologies, Carlsbad, CA) and used to transform TOP10 E. coli. Transformants were screened for Vk10 A, B or C plasmids by colony lift and blotting with ${ }^{32}$ P-labeled Vк10A, B or C-specific oligonucleotides as previously described [39]. Isolated plasmids containing $\mathrm{V} \kappa 10 \mathrm{~A}, \mathrm{~B}$ and $\mathrm{C}$ rearrangements to $\mathrm{J} \kappa 1$ were verified by sequencing and used as standards for qPCR.

Quantitative PCR's for each Vk10 gene utilized the Gen11 upstream primer, the downstream primer Vк10FW3Rev1 (5'-agacccactgccactgaaccttgatg- $\left.3^{\prime}\right)$ and unique FAMTAMRA probes for Vk10A (5'-taaataattgctaatgtcctga cttgccct-3'), Vк10B (5'-taaataattgctaatgccetgacttgcact- $\left.3^{\prime}\right)$ and VK10C (5'-taaataagtgctaatgtcctcacttgccet-3'). The Gen11 and Vk10FW3Rev1 primers bind to identical sites in all three $V_{\kappa} 10$ genes while the unique probes differ from each other by several bases.

$\mathrm{V \kappa} 10 \mathrm{~A}, \mathrm{~B}$ and $\mathrm{C}$ targets from sorted pre-B cell and whole spleen $\mathrm{CDNA}$ were quantified relative to dilutions of the Vk10A, B and C plasmid standards. Each Vk10 standard was diluted from $2 \times 10^{6}$ femtograms (fg) per reaction to $2 \mathrm{fg}$ per reaction. Reaction plates included triplicate standard dilutions, duplicate cDNA samples and cross-detection controls to ensure that each probe was specific for its target. Threshold cycles $(\mathrm{Ct})$ for each dilution of standard were used to construct a standard curve and sample concentrations were determined by interpolation of sample Ct into the standard curves.

\section{Vk10 promoter reporter vector construction, transfection and luciferase assays}

Construction of the pGL3 vectors containing only the $\kappa$ enhancer (ken) and the Vk10A (AS) or Vk10C (CS) short/minimal promoter fragments plus the kappa enhancer were previously described [40]. The Vk10C mutated promoters S1, S2 and S3 were synthesized by site directed mutagenesis of the pGL3kenCS plasmid using the Transformer Site-directed Mutagenesis kit (Clontech, Mountain View, CA). Mutated promoters from the site mutation reactions were subsequently PCR-amplified and ligated into pGL3кеn. Orientation and promoter sequence confirmation were determined by sequencing. The $\mathrm{Vk} 10 \mathrm{C}$ promoter was mutated such that a specific Vk10C nucleotide was changed to that of Vk10A. The S1 mutation introduces an additional "A" upstream of the octamer in Vk10C, S2 introduces a $\mathrm{C} \rightarrow \mathrm{G}$ mutation in the $5^{\prime}$ E-box and S3 introduces a $\mathrm{C} \rightarrow \mathrm{A}$ mutation in the $3^{\prime}$ region of the promoter.
All plasmids, including the control vector pCMV- $\beta$, (Clontech, Palo Alto, CA) were purified by double-banding in cesium chloride.

Transfections, lysate production and luciferase and $\beta$-galactosidase assays were performed as previously described [40]. Briefly, NFS-5 and 18-81 pre-B cells were co-transfected with $\mathrm{pCMV}-\beta$ and either the AS, CS, S1, S2, S3 or ken vectors and cultured for 24 hours. After 24 hours, cells were harvested, lysed and assayed for luciferase and $\beta$-galactosidase production on a luminometer in 96-well Microlite I plates (Dynatech, Chantilly, VA). Luciferase activity was normalized by dividing the luciferase value by the $\beta$-galactosidase value for each well. Statistical comparisons were performed using a two sample T-test with unequal variance.

\section{Construction and screening of $\mathrm{Vk} 10 / \mathrm{HC}$ phage libraries for pairing analysis}

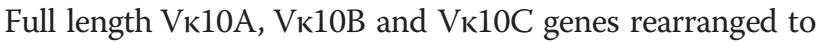
Jk1 were obtained by RT-PCR of BALB/c spleen cDNA. The five-prime Vk10 primers spanned codons 1-10 and included XhoI restriction sites (Vк10A/B Xho 5' -ctccaggtc gacctcgaggatatccagatgacacagactacatcctcc-3', Vк10C Xho $5^{\prime}$-ctccaggtcgacctcgaggatatccagatgacacagactacttcctcc-3'). The three-prime $\mathrm{Ck}_{k} A s c \mathrm{I}\left(5^{\prime}\right.$-tagaataggcgcgcttattatctaa cactcattcctgttgaagc- $3^{\prime}$ ) primer was specific for the last six codons of the kappa constant region and contained an Asc1 restriction site. Amplified Vk10A/B/C/Jk1Ck PCR products were first cloned into the pCR4-TOPO vector. pCR4-TOPO Vk10 clones were subsequently digested with $X h o I$ and $A s c I$ and purified inserts were ligated into similarly digested pCES phagemid vector [41]. Vк10 sequences were confirmed by sequencing.

Heavy chain VDJ-CH1 rearrangements were amplified from cDNA from total RNA of LPS-stimulated splenic B cells (two individual mice), sorted pre-B cells (pooled from 5 mice) and from pre-B cells expanded ex-vivo on OP-9 stromal cells stimulated with IL-7 [22]. H-chain gene repertoires were amplified from the cDNA with the FastStart Fidelity PCR System (Roche, Basel, Switzerland) in combination with framework $1 \mathrm{VH}$ primers [42] containing $S f i \mathrm{I}$ restriction sites and a reverse IgM $\mathrm{CH} 1$ primer $\left(5^{\prime}\right.$-gagtcattctcgactgcggccgctggaatgggcacatgcaga tctctgttttgcc- $\left.3^{\prime}\right)$ containing a NotI restriction site. $\mathrm{VH}$ PCR reaction conditions were $95^{\circ} \mathrm{C}$ for $5 \mathrm{~min}, 95^{\circ} \mathrm{C}$ for $1 \mathrm{~min} / 50^{\circ} \mathrm{C} 1 \mathrm{~min} / 72^{\circ} \mathrm{C} 1 \mathrm{~min}$ ( 35 cycles), $72^{\circ} \mathrm{C}$ for $7 \mathrm{~min}$, and a $4^{\circ} \mathrm{C}$ hold. $\mathrm{H}$-chain PCR products were digested with restriction enzymes SfiI and NotI and gel-purified. $350 \mathrm{ng}$ of the purified $\mathrm{H}$-chain DNA PCR products were ligated into $1 \mu \mathrm{g}$ of gel-purified, SfiI- and NotI-digested pCES phagemids containing a fixed $\mathrm{V} \kappa 10 \mathrm{~A}, \mathrm{~B}$ or $\mathrm{C}$ Јк1-Ck gene with $10 \mu \mathrm{l}$ T4 Ligase (Life Technologies, Carlsbad, CA) in a $200 \mu \mathrm{l}$ reaction overnight at room temperature. Ligations were precipitated, resuspended in $15 \mu \mathrm{l}$ of $\mathrm{H}_{2} \mathrm{O}$ and 
electroporated into $300 \mu \mathrm{l}$ of $E$. coli strain XL-1 Blue (Stratagene, La Jolla, CA) in $2 \mathrm{~mm}$ cuvettes (BioRad, Hercules, CA) with a BioRad Gene pulser set at $2.5 \mathrm{kV}, 200 \Omega$, and $25 \mu \mathrm{F}$. Electroporated cells were added to $5 \mathrm{ml}$ of $\mathrm{LB} /$ ampicillin, grown for one hour at $37^{\circ} \mathrm{C}$ and the entire library was spread onto LB/ampicillin plates and incubated overnight at $37^{\circ} \mathrm{C}$. Colonies were scraped from the plates and saved as glycerol stocks. In total, 10 libraries were generated, each with a complexity of $\sim 1 \times 10^{7}$ total cfu.

Forty $\mu$ l of each library was used for library expansion and subsequent phage rescue using M13K07 helper phage. Phage expressing $\mathrm{V} \kappa 10 / \mathrm{H}$ chain $\mathrm{F}_{\mathrm{Ab}}$ were rescued from each library, PEG-precipitated and resuspended in $1 \mathrm{ml}$ PBS. Each phage library was subjected to two rounds of selection, first on 96-well plate wells (two wells) coated with $500 \mathrm{ng}$ goat anti-k antibodies (Southern Biotechnology, Birmingham, AL) and second on two wells coated with $500 \mathrm{ng}$ goat anti- $\mu$ antibodies (Southern Biotechnology, Birmingham, AL). For each selection, wells of a 96 well plate were coated with antibody overnight at $4^{\circ} \mathrm{C}$ in coating buffer (sodium bicarbonate buffer) and then blocked with $300 \mu \mathrm{l} /$ well of $1 \% \mathrm{BSA} / \mathrm{PBS}$ for one hour at $37^{\circ} \mathrm{C}$. Fifty $\mu \mathrm{l}$ of freshly prepared phage in PBS was added to each well (2 wells per library) and incubated for two hours at $37^{\circ} \mathrm{C}$. Wells were washed ten times with $300 \mu \mathrm{l}$ PBS/0.05\% Tween 20, bound phage were eluted with $50 \mathrm{ul}$ of $100 \mathrm{mM}$ glycine- $\mathrm{HCl} \mathrm{pH} 2.2$ and then neutralized with $3 \mu \mathrm{l}$ of $2 \mathrm{M}$ Tris. Ten $\mu$ l of neutralized phage was then used to re-infect XL-1 Blue cells. Phage were rescued and purified as described above and the selection process was repeated on anti- $\mu$ coated wells. XL-1 Blue cells were infected with phage eluted during the second round of selection and plated on LB/ampicillin plates. Phagemid DNA from approximately 300 individual bacterial colonies per library were purified and sequenced. Sequences were compared against the existing $\mathrm{VH}$ sequence data for the C57BL/6 and 129S1 strains.

\section{PCR of VK10JK1 displaced by secondary rearrangements to JK2}

Genomic DNA was isolated from BALB/c spleen cells and sorted pre-B cells and PCR was performed using primers designed to amplify $\mathrm{V} \kappa 10$ rearrangements that were displaced, but retained in the genome by secondary inversional $\mathrm{VK}$ gene rearrangements to J 2 . VК10JK1 products were amplified with the Gen 9 primer ( 5 ' -tccagatgacacagactac-3'), which binds the identical sequence in framework 1 of all Vk10 genes and the Jk2HepNanR 3' primer (5' -gbytgwakcactgtgcacagtggtgtcccttc actca-3') that includes a portion of the Jk2 RSS 23 bp spacer, the back-to-back $V_{k x} / J_{K} 2$ heptamers and part of the RSS $12 \mathrm{bp}$ spacer consensus of $\mathrm{Vk}$ genes. The sequence of the
$12 \mathrm{bp}$ Vkx spacer portion of the primer was designed by construction of a consensus sequence from published $\mathrm{Vk}$ gene sequences [7-9]. PCR conditions were as follows: $95^{\circ} \mathrm{C}$ for $5 \mathrm{~min}, 95^{\circ} \mathrm{C}$ for $30 \mathrm{sec}, 55^{\circ} \mathrm{C}$ for $30 \mathrm{sec}, 72^{\circ} \mathrm{C}$ for $1 \mathrm{~min}$, repeated for 35 cycles, with a final extension of $72^{\circ} \mathrm{C}$ for $7 \mathrm{~min}$. PCR products were ligated into the pCR4-TOPO vector and $2 \mu \mathrm{l}$ of the ligation reactions were transformed into TOP10 E. coli cells. Two-hundred randomly chosen clones from each transformation were grown overnight, purified with Montage Plasmid Miniprep Kit (Millipore, Billerica, MA) kit and sequenced.

\section{PCR of $V_{K} J_{K}$-iRS recombination}

Genomic DNAs were isolated from spleens of 4 BALB/cAnNCr mice using the Genomic Prep Cells and Tissue DNA Isolation Kit (Amersham Pharmacia Biotech, Piscataway, NJ) or Trizol according to manufacturers' instructions. PCR included the Gen 9 five-prime primer and the three-prime RS-101 primer (5'-acatg gaagttttccoggagaatatg- $\left.3^{\prime}\right)$, which anneals in the RS sequence [43]. Six replicate PCRs were performed using the GeneAmp XL PCR kit (Life Technologies). Each reaction contained $100 \mathrm{ng}$ genomic DNA; $800 \mu \mathrm{M} \mathrm{Mg}$ $(\mathrm{OAc})_{2} ; 2$ units rTth DNA polymerase XL; $200 \mu \mathrm{M}$ each dNTP and 20 picomol each primer. Amplification was performed in a DNA Thermal Cycler 480 (PE Biosystems, Foster City, CA) at $93^{\circ} \mathrm{C}$ for 1 minute, followed by 35 cycles of $93^{\circ} \mathrm{C}$ for 1 minute, $59^{\circ} \mathrm{C}$ for 1 minute, and $72^{\circ} \mathrm{C}$ for 2.5 minutes with final extension for 10 minutes at $72^{\circ} \mathrm{C}$. Replicate PCR products were pooled, precipitated, and ligated into pCR2.1-TOPO vector (Life Technologies, Carlsbad, CA).

\section{Results}

\section{The $\mathbf{V}_{\mathbf{k}} 10 \mathrm{C}$ promoter is inefficient in pre-B cells}

We assessed levels of $\mathrm{V} \kappa 10$ transcripts in freshly isolated pre-B cells and spleen using qPCR. Vк10C mRNA levels in $\mathrm{IgM}^{-} / \mathrm{CD} 43^{-} / \mathrm{B} 220^{+}$pre-B cells from 4 independent sorts are 4-10 fold lower than $\mathrm{V}_{\kappa} 10 \mathrm{~A}$ and $\mathrm{V} \kappa 10 \mathrm{~B}$, respectively (Figure 1A). Vк10A and $V_{\kappa} 10 B$ levels in the spleen were elevated 7-8 fold compared to levels in pre-B cells, but Vк10C was not detected (Figure 1B).

We next examined the effect of mutations in the Vк10C promoter to drive luciferase expression in transient transfection assays. The $\mathrm{Vk} 10 \mathrm{~A}$ and $\mathrm{V} \kappa 10 \mathrm{C}$ promoters differ by four nucleotides over an approximately $130 \mathrm{bp}$ region (Figure $2 \mathrm{~A}$ ). In luciferase reporter gene assays, the VK10C promoter has a significantly lower efficiency than the Vk10A promoter in the pre-B cell lines 70Z/3, NFS-5, NFS-467, and 18-81, but is equally efficient in immature, mature and plasma cell lines [40]. Here, we introduced single mutations at three positions into the Vk10C promoter to resemble the $\mathrm{V} \kappa 10 \mathrm{~A}$ promoter and placed each mutated promoter upstream of the luciferase reporter 


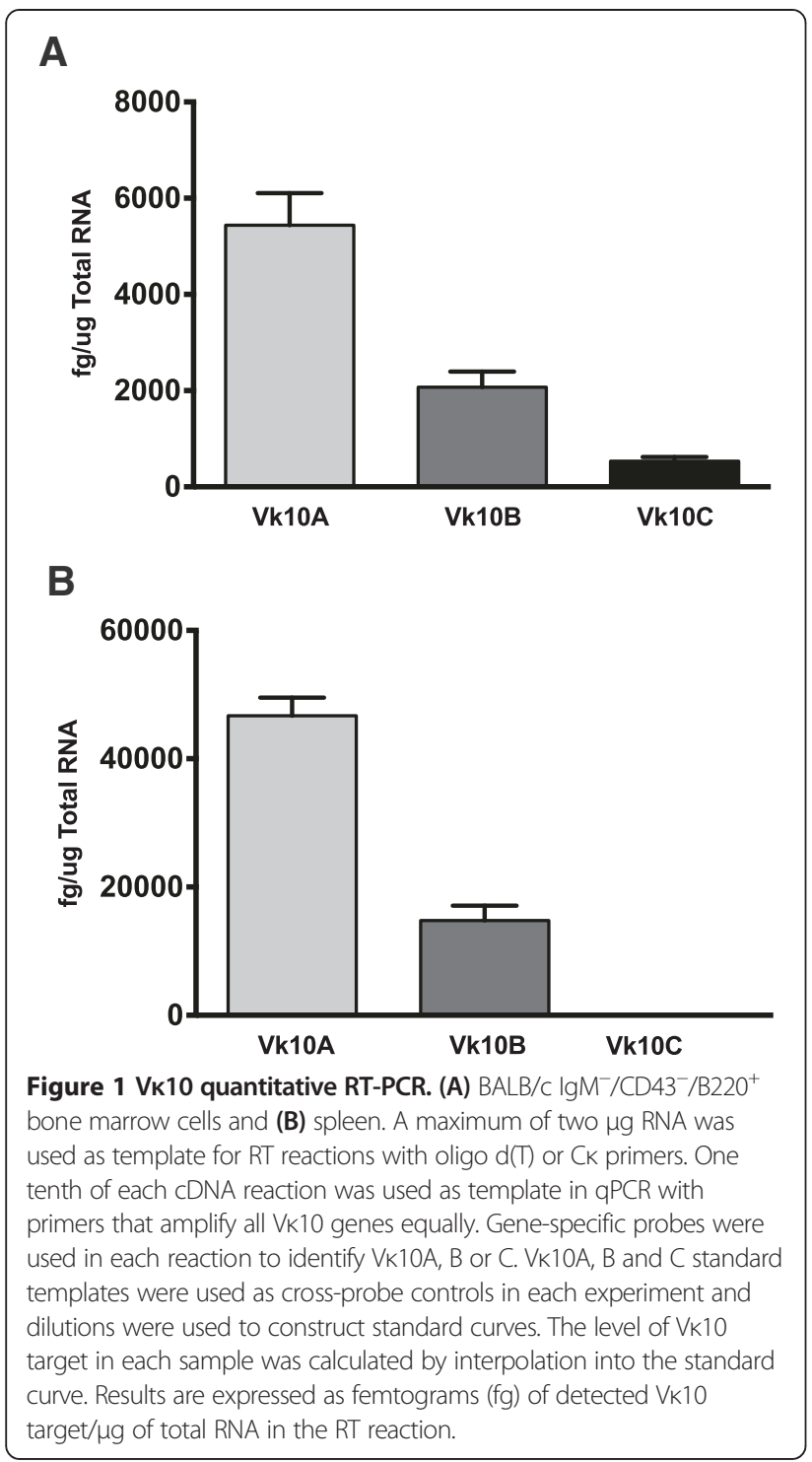

gene in pGL3ken [40], which contains the kappa intronic enhancer downstream of the luciferase reporter gene. We did not make the $\mathrm{C} \rightarrow \mathrm{G}$ mutation upstream of the pentadecamer as the germline sequence available for VK10A at the time did not show this difference.

Promoter efficiency of the mutated Vk10C promoters at site 1 , site 2 and site $3(\mathrm{~S} 1, \mathrm{~S} 2, \mathrm{~S} 3)$ was assessed in transient transfection assays using NFS-5 and 18-81 pre-B cell lines. The unmutated short/minimal VK10A

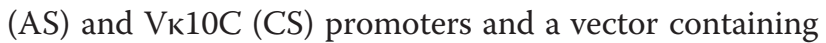
only the kappa enhancer (кen) were included as controls. As expected, a highly significant difference $(\mathrm{p}<0.0001)$ was observed between the activity of the unmutated AS and CS minimal promoters in NFS-5 (Figure 2B) and 18-81 (Figure 2C) cells, while vector containing only the kappa enhancer exhibited little activity. By mutating the site 3 (S3) nucleotide $\left(\mathrm{A} \rightarrow \mathrm{C}\right.$, at the $3^{\prime}$ end of the promoter), luciferase expression was consistently and reproducibly increased in pre-B cells to a level comparable to that attained with the AS vector $(\mathrm{p}<0.0001$, Figure $2 \mathrm{~B}$ and C). Mutations to site 1 (S1; upstream of the octamer) and site 2 (S2; 5' E-box) marginally improved promoter function, but did not yield consistently reproducible results between the two pre- $\mathrm{B}$ cell lines (Figure $2 \mathrm{~B}$ and $\mathrm{C}$ ). Together, these data suggest that the Vк10C promoter is less efficient than the Vк10A promoter in pre-B cells and pre-B cell lines, specific sequences control promoter efficiency, and splenic B cells expressing Vк10C L chains are rare so that Vk10C transcripts cannot be detected.

\section{Vк10C L chain pairs efficiently with different $H$ chains}

The ability of $\mathrm{VK}_{\mathrm{K}} 10 \mathrm{~L}$ chains to pair with a diverse array of $\mathrm{H}$ chains was tested in a phage display format that expresses $\mathrm{F}_{\mathrm{Abs}}$. The $\mathrm{H}$ chain is expressed as a fusion protein with the phage coat protein gIII, while the L chain is soluble and pairs with the $\mathrm{H}$ chain in the periplasmic space to form the $\mathrm{F}_{\mathrm{Ab}}$; hence, only VK10 L chains that can successfully pair with $\mathrm{H}$ chains would be expressed on the phage surface. Two libraries for each Vk10 gene were generated from LPS-stimulated splenic B cells from two mice. The data from both libraries for each Vk10 gene were pooled for analysis. A pool of sorted pre-B cells from 5 mice was used to generate a pre-B cell library for each Vk10 gene. One additional Vk10C library was generated from a single mouse (also used to construct the second set of $B$ cell libraries) whose pre-B cells were expanded ex-vivo on OP9 stromal cells stimulated with IL-7 [22]. The results from the two Vk10C pre-B cell libraries were pooled for analysis. The $\mathrm{H}$ chain sequences obtained from each library were identified by comparison with germline $\mathrm{H}$ chain gene sequences in the IgBLAST database [44]. BALB/c mice share a VH haplotype with 129S1 mice and $\mathrm{H}$ chain sequences from the 129S1 strain have been reported for all but the most $5^{\prime} \mathrm{H}$ chain families [45]. Accordingly, the majority of our $\mathrm{H}$ chain sequences show the greatest homology to 129S1 H chain sequences while others are identified using germ line $\mathrm{H}$ chain gene sequences from different strains in the database.

Roughly three hundred clones from each library (3000 total) were sequenced to allow an observation of an event occurring at a frequency as low as $1 \%$. Figure $3 \mathrm{~A}$ depicts the fixed Vк10Jк1 sequences used in the pairing experiments. The number of individual $V_{H}$ chains per $\mathrm{V}_{\mathrm{H}}$ family that were paired with $\mathrm{V}_{\kappa} 10 \mathrm{~A}, \mathrm{~V}_{\kappa} 10 \mathrm{~B}$ and Vк10C in pre-B cell and splenic B cell libraries are shown in Figure $3 B$ and $C$, respectively. In the pre- $B$ cell libraries (Figure 3B), Vk10C paired with $\mathrm{V}_{\mathrm{H}}$ chains from 12 of $15 \mathrm{~V}_{\mathrm{H}}$ gene families (67 unique VDJ sequences), while $V \kappa 10 A$ paired with $V_{H}$ chains from 7 families (46 

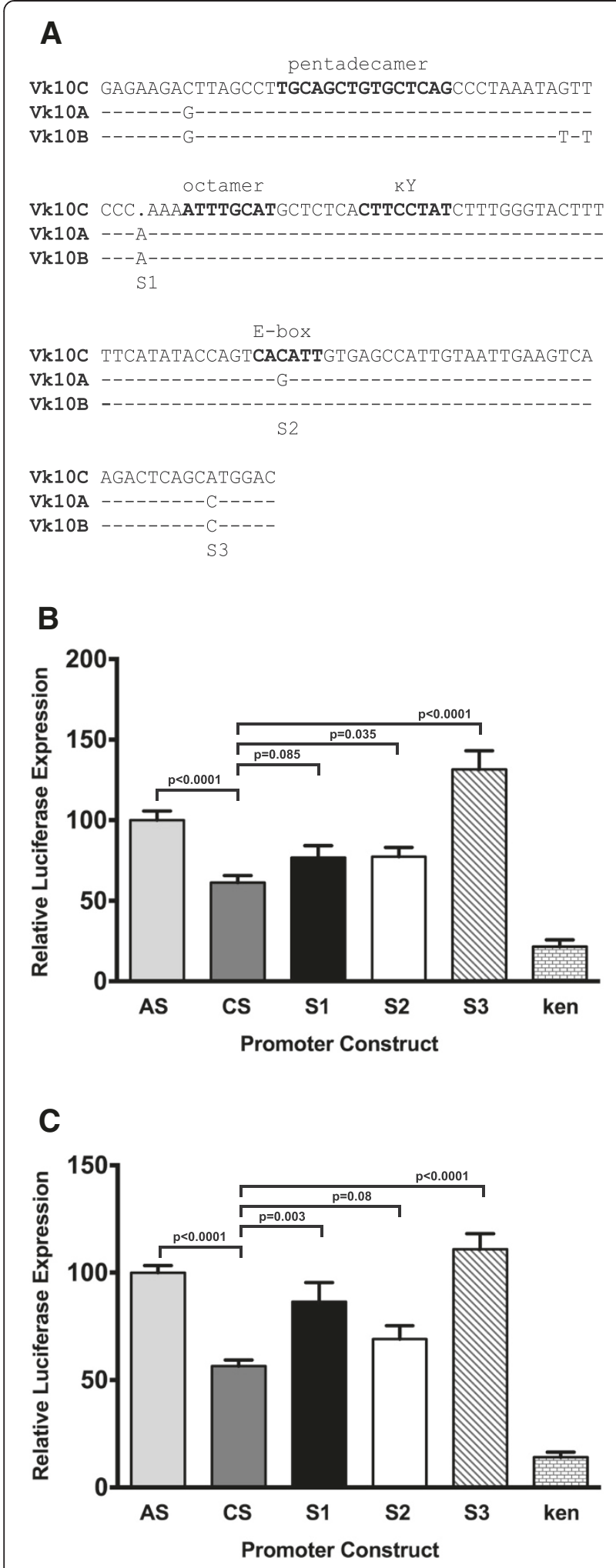

Figure $\mathbf{2}$ Vк10 promoter efficiency in pre-B cells. (A) Nucleic acid sequence comparison of the $V_{K} 10$ promoters. S1, S2 and S3 indicate the positions in the $V_{k} 10 C$ promoter that were mutated to the $V_{k} 10 A$ sequence. Mutated $V_{K} 10$ promoters were cloned into the $P G L 3$ luciferase reporter vector containing the $k$ intronic enhancer (Ken). Known regulatory sequences are in bold. PGL3kenAS, PGL3kenCS, PGL3kenS1, PGL3kenS2, PGL3kenS3 and PGL3ken were co-transfected with the control vector pCMV- $\beta$ into (B) NFS-5 pre-B cells in 3 separate experiments ( $n=15$ for AS, CS, S1, S2, S3, $n=9$ for ken) and (C) 18-81 pre-B cells in 7 separate experiments ( $n=33$ for $A S, C S, S 1, S 2, S 3, n=17$ for ken). Luciferase expression was assayed after 24 hours and differences in VK10A and VK10C promoter-driven expression of luciferase were compared by $\mathrm{T}$-test. Error bars represent standard error of the mean. AS and CS are abbreviations for the Vk10A and $V_{K} 10 C$ short/minimal promoter sequence.

unique VDJ sequences) and $\mathrm{VK} 10 \mathrm{~B}$ paired with $\mathrm{V}_{\mathrm{H}}$ chains from 8 families (41 unique $V$ sequences). A diverse pattern of pairing for all three $\mathrm{Vk} 10$ family members was also observed in the splenic B cell libraries (Figure 3C). Here Vк10A, Vк10B and Vк10C $L$ chains each paired with $V_{H}$ chains from 9 different $V_{H}$ families using 35, 40 and 57 unique VDJ sequences, respectively. These data demonstrate that $\mathrm{V} \kappa 10 \mathrm{C}$ is not deficient in its ability to pair with $\mathrm{V}_{\mathrm{H}}$ chains and in fact, exhibits a broader spectrum of pairing with unique $V_{H}$ chains than the other members of the Vк10 family in both pre-B and B cells.

\section{Productive VK10C rearrangements are eliminated by receptor editing and $\mathrm{RS}$ recombination}

We next examined the possibility that the loss of productive $\mathrm{V} \kappa 10 \mathrm{C}$ rearrangements is the result of editing by secondary recombination. Secondary recombination can replace productive and non-productive $\mathrm{V} \kappa \mathrm{J} \kappa$ recombinations via deletion or inversion, depending on the transcriptional orientation of the $V_{K}$ gene relative to $\mathrm{JK}_{\mathrm{K}}$ [46]. Inversion events result in the retention of the original $\mathrm{VK} \mathrm{JK}$ rearrangement in the genomic DNA upstream of the back-to-back RSS structure derived from the secondary recombination (Figure 4A). The presence of these edited primary rearrangements does not influence the selection events leading to the ultimate fate of the B cell, which is based on the expressed antibody, but reflects the recombination history of the B cell. Rearrangement in only one of three reading frames would be productive and the other two reading frames would be nonproductive (a non-productive to productive ratio of $2: 1$ ). If the loss of productive $\mathrm{V}_{\kappa} 10 \mathrm{C}$ rearrangements is largely due to negative selection resulting in receptor editing, we would expect a greater percent of in-frame Vk10CJk displaced by secondary rearrangements. PCR was performed to amplify primary VК10JK1 rearrangements that were displaced by secondary inversional $\mathrm{Vk}$ gene rearrangements to $\mathrm{J} \kappa 2$. In-frame and out of frame rearrangements of all three $\mathrm{V} \kappa 10$ genes were detected in $\mathrm{B}$ and pre-B cell genomic DNA (Figure 4B). 


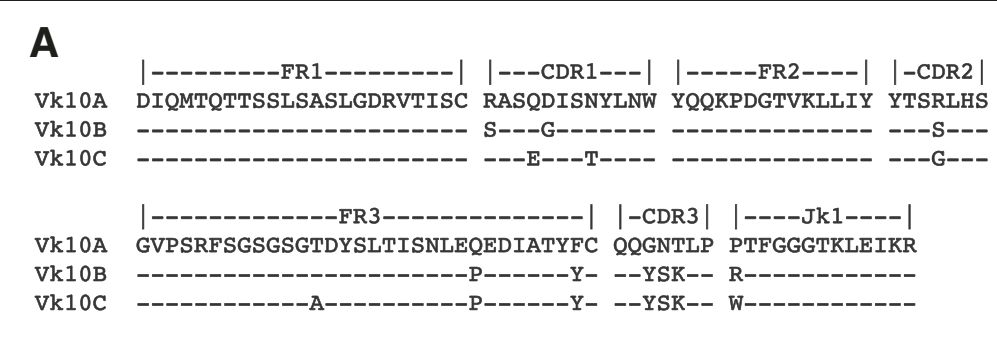

\section{B}

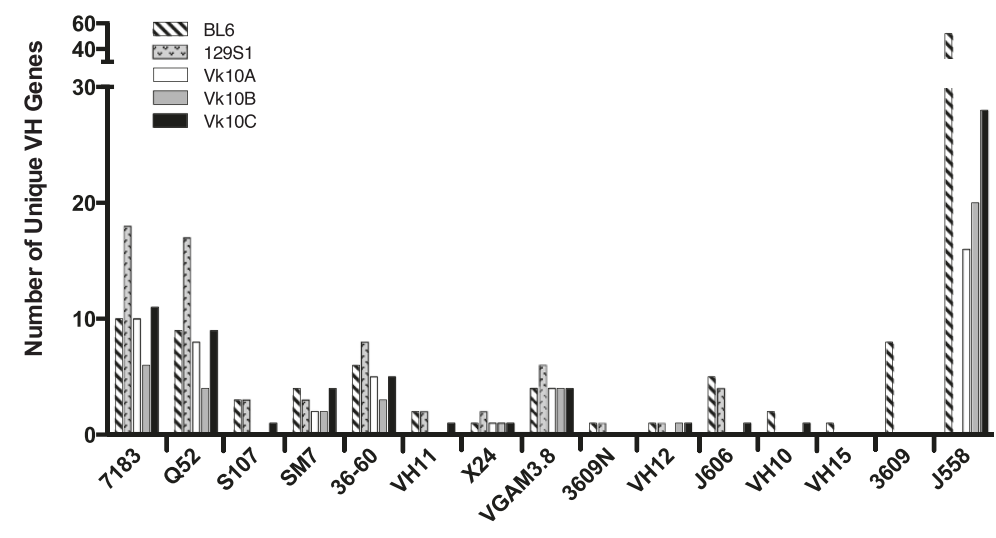

VH Gene Families

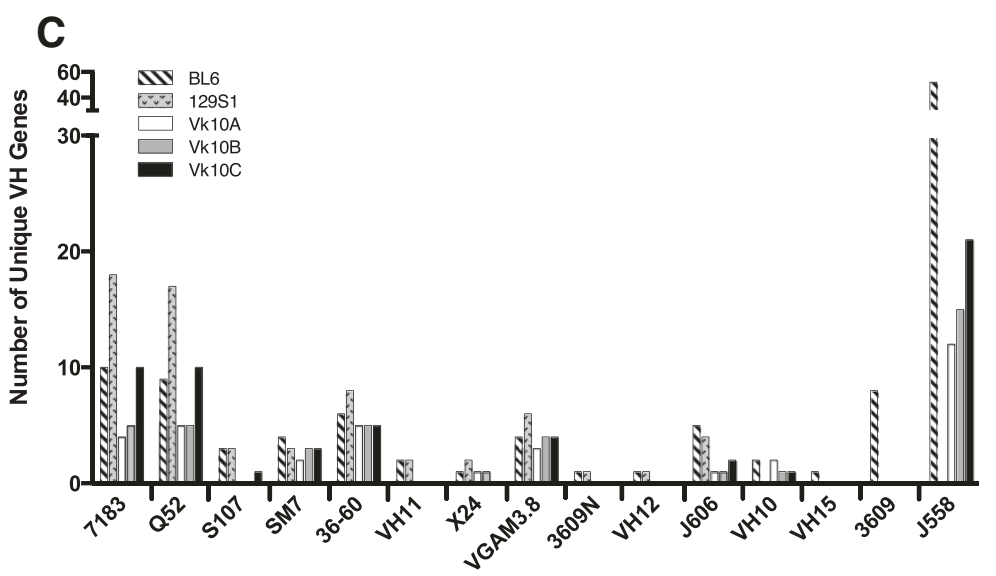

VH Gene Families

Figure 3 VK10 light chain pairing with heavy chain. (A) Alignment of the $V_{K} 10 A J_{K} 1, V_{K} 10 B J_{K} 1$ and $V_{K} 10 C J_{K} 1$ amino acid sequences derived from rearrangements amplified by PCR and cloned separately into the phagemid vector pCES (CK is not shown but is identical for all). (B) VH genes amplified from pre-B cells and (C) VH genes amplified from splenic B cells. VDJ-CH1 rearrangements were amplified from CDNA derived from total RNA of LPS-stimulated splenic B cells (two mice separately), sorted pre-B cells (pooled from 5 mice) and from pre-B cells expanded ex-vivo on OP-9 stromal cells stimulated with IL-7. Phage expressing both $\mu$ and $k$ were selected by sequential panning on anti-k and anti- $\mu$ coated surfaces and sequenced. The genomic linear order of $V_{H}$ gene families from five prime to three prime is shown on the bottom of each graph. Bars with diagonal lines and gray stippled bars represent the number of germ line $V_{H}$ sequences in each $V_{H}$ family for C57BL/6 and 129S1 mice, respectively. White, gray and black bars show the number of unique $V_{H}$ sequences isolated for each $V_{H}$ family that paired with $V_{K} 10 A$, $V_{K} 10 B$ and VK10C, respectively.

In both pre- $\mathrm{B}$ cells and splenic $\mathrm{B}$ cells the majority of total

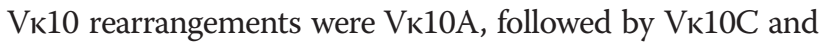
Vк10B (Table 1). In pre-B cells, the non-productive (NP) to productive $(\mathrm{P})$ recombination ratio for displaced Vк10A and $\mathrm{VK} 10 \mathrm{~B}$ rearrangements was the expected ratio of $\sim 2.0$, while the NP/P ratio for $\mathrm{V} \kappa 10 \mathrm{C}$ was $\sim 1.0$, indicating equal displacement of non-productive and productive Vк10CJк1 rearrangements. In $\mathrm{B}$ cells, the $\mathrm{NP} / \mathrm{P}$ ratios of displaced $\mathrm{VK} 10 \mathrm{~A}$ and $\mathrm{V \kappa} 10 \mathrm{~B}$ rearrangements is $<1.0$, but remains $\sim 1.0$ for $\mathrm{Vk} 10 \mathrm{C}$. These data suggest that there may be some negative selection of primary $\mathrm{V} \kappa 10 \mathrm{C}$ rearrangements as reflected by the NP/P ratio in both pre-B and B 

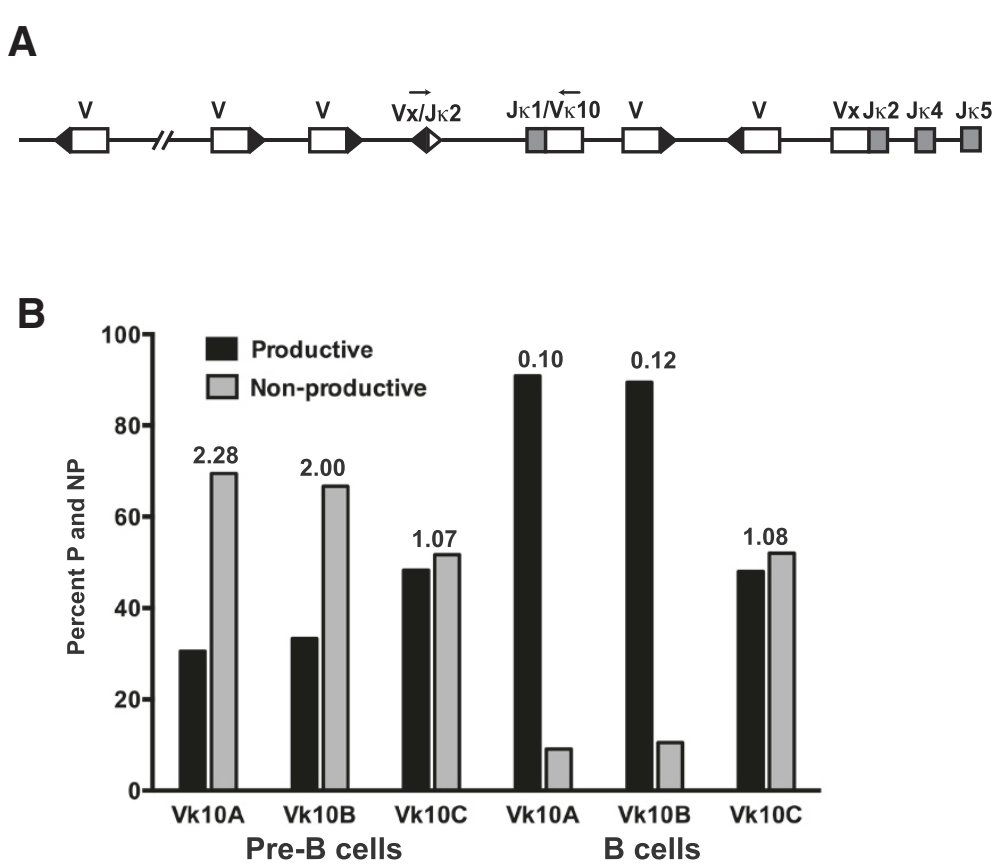

Figure 4 Editing of $V_{\kappa} 10 J_{K} 1$ rearrangements by secondary $V_{K}$ inversion type rearrangements to JK2. (A) Schematic of $V_{K} 10 J_{K} 1$ rearrangement displaced by subsequent inversional secondary VK rearrangement to JK2. Open boxes represent $V_{K}$ genes, black triangles next to open boxes represent VK RSS sequences, grey boxes represent JK genes and the back-to-back open and black triangle represent the back-to-back $J_{K} 2$ and $V_{K X}$ RSS, retained on the genomic DNA. Arrows represent the PCR primers used to amplify the displaced $V_{K} 10 J_{K} 1$ rearrangement. The upstream primer anneals in $V_{k} 10$ framework 1 to a sequence that is identical for all $V_{k} 10$ genes. The downstream primer was designed to include a portion of the JK2 23 bp spacer, the back-to-back $V_{K X} / J_{k} 2$ heptamers and part of the 12 bp space consensus sequence of other $V_{k}$ genes. (B) Percent of productive and nonproductive recombination products of displaced VK10A, VK10B and VK10C in BALB/c pre-B cells and B cells. The NP/P ratio is listed above each set of bars.

cells. For Vk10A and Vk10B, the NP/P ratio in pre-B cells reflects the expected outcome of primary recombination events, but the low NP/P ratios seen in B cells suggests higher rates of negative selection occurring between the pre-B cell stage and the mature B cell population.

Recombination to RS is an alternate mechanism of receptor editing. $\mathrm{VKJK}$ rearrangements are retained on alleles when the recombination is between an isolated heptamer in the $\mathrm{J} K-\mathrm{CK}_{\mathrm{K}}$ intron and the RS element $25 \mathrm{~kb}$ downstream of $\mathrm{Ck}$ (VkJk-iRS; Figure 5A). The $\mathrm{NP} / \mathrm{P}$ ratios for $\mathrm{Vk} 10$ rearrangements on $\mathrm{VkJK}$-iRS alleles in splenic B cells were $\sim 1$ for $\mathrm{V \kappa} 10 \mathrm{C}$ and $>>2$ for Vk10A and Vk10B (Table 1, Figure 5B). The Vk10C data are consistent with the secondary recombination data, suggesting some negative selection of productive Vk10C recombination products.

Table 1 Vк10 editing by secondary rearrangements to VкJк2

\begin{tabular}{|c|c|c|c|c|c|c|c|c|}
\hline & \multicolumn{4}{|c|}{ VKJK2 editor } & \multicolumn{4}{|c|}{ VKJK-iRS } \\
\hline & Total & Non-productive & Productive & $N P / P^{a}$ & Total & Non-productive & Productive & $N P / P^{a}$ \\
\hline \multicolumn{9}{|l|}{ Pre-B } \\
\hline Vк10A & 82 & 57 & 25 & 2.28 & ND & ND & ND & ND \\
\hline Vк10B & 36 & 24 & 12 & 2.00 & ND & ND & ND & ND \\
\hline Vк10C & 58 & 30 & 28 & 1.07 & ND & ND & ND & ND \\
\hline \multicolumn{9}{|l|}{ Spleen } \\
\hline Vк10A & 77 & 7 & 70 & 0.1 & 58 & 49 & 9 & 5.4 \\
\hline Vк10B & 19 & 2 & 17 & 0.12 & 19 & 18 & 1 & 18 \\
\hline Ук10C & 25 & 13 & 12 & 1.08 & 69 & 36 & 33 & 1.09 \\
\hline
\end{tabular}

${ }^{\mathrm{a}} \mathrm{NP} / \mathrm{P}=$ non-productive to productive recombination ratio. $\mathrm{ND}=$ not done. 

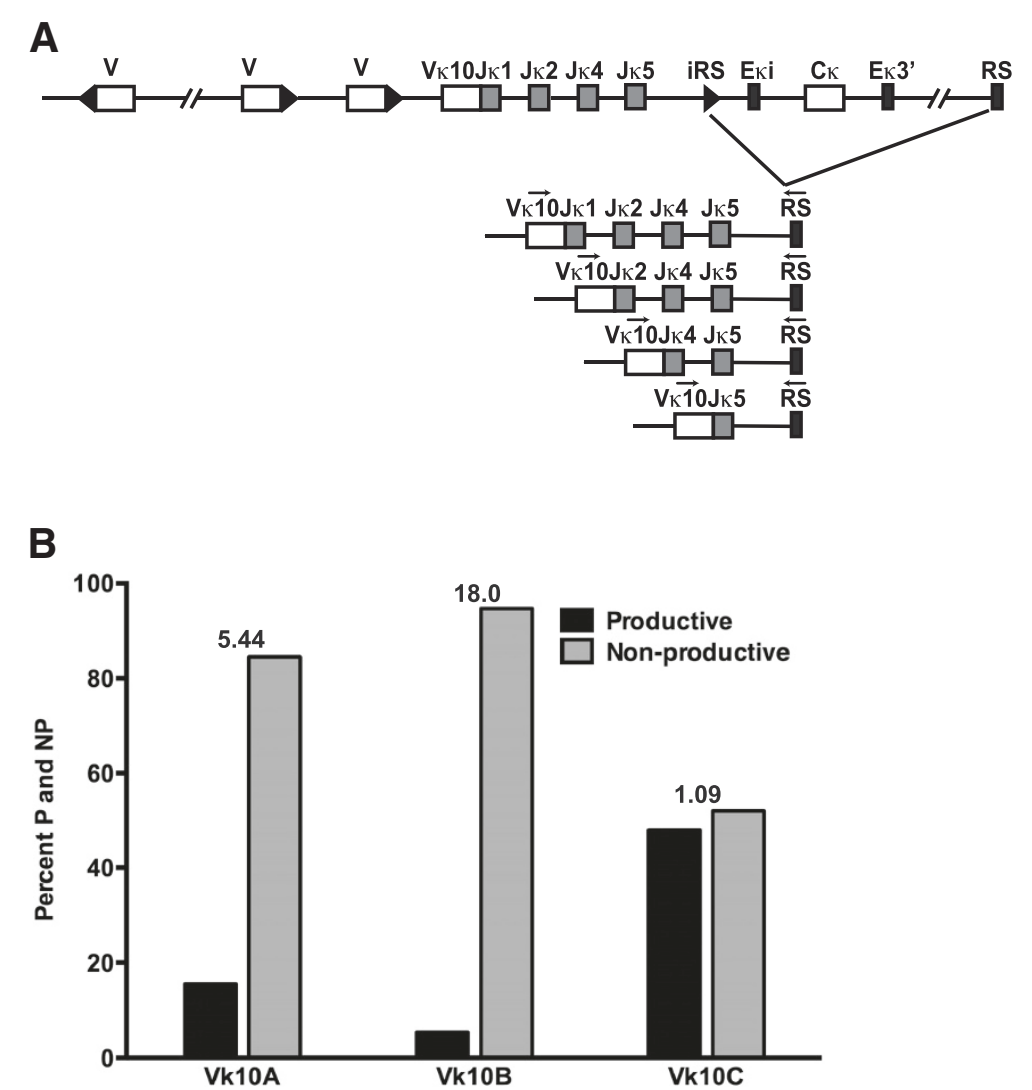

Figure 5 VKJK-iRS receptor editing of Vk10 productive and nonproductive rearrangements. (A) Schematic of the kappa locus (not drawn to scale) depicting $V_{K} J_{K}$-iRS recombination products resulting from recombination of the RS element with an isolated heptamer in the $J_{K}$ - $C_{K}$ intron. Arrows represent the PCR primers used to amplify the edited $V_{K} 10 J_{K}$ rearrangement. The upstream primer anneals in $V_{k} 10$ framework 1 to a sequence that is identical for all $V_{k} 10$ genes. The downstream primer anneals to a sequence in the RS. (B) Percent of productive and nonproductive recombination products of RS edited $V_{K} 10 A, V_{K} 10 B$ and $V_{k} 10 C$ rearrangements to JK1, JK2, JK4 and JK5.

\section{Discussion}

The primary naïve antibody repertoire is shaped by events that occur during B cell development in the bone marrow as well as events that happen once an immature B cell emigrates from the bone marrow and transitions to a mature follicular, marginal zone or B1 B cell. Transgenic and knock-in mouse models expressing antibody genes have been invaluable in demonstrating a primary role for receptor editing in the establishment of central B cell tolerance. When opportunities for receptor editing are limited, newly formed B cells in the bone marrow can be rendered anergic or undergo deletion. It's been estimated that fewer than half of newly formed B cells emigrate from the bone marrow each day [47]. The fate decisions of developing B cells are influenced by levels of BCR expression and tonic signaling, where a reduction in basal levels of tonic signaling leads to impaired maturation of pre-B cells to immature $B$ cells, de-differentiation of the newly formed B cell, and light chain receptor editing, while elevated levels of tonic signaling lead to increased RAG expression and receptor editing [48-56].
A threshold of BCR expression and tonic signaling ultimately determines whether a $\mathrm{B}$ cell moves to the periphery or undergoes additional rounds of $\mathrm{L}$ chain recombination [57-59].

Our Vk10 system offers the unique advantage of examining the factors that determine the inclusion or exclusion of a highly homologous family of VK LC's in the antibody repertoire during normal development in the context of unmanipulated genetic backgrounds. The VK10 L chain family consists of three highly homologous structurally functional genes with dramatic differences in usage patterns $[39,40]$ Vk10A is highly utilized and represents between $2.9 \%$ to $12 \%$ of all $\mathrm{VK}$ gene usage in bone marrow, spleen and lymph nodes while VK10B is utilized to a lesser extent, representing between $1.7 \%$ and $3.5 \%$ of $\mathrm{VK}$ gene usage in these compartments [16,39]. TheVk10C gene is rarely utilized and has been shown to be present at a frequency of $0.15 \%$ in BALB/c spleen B cell cDNA libraries [39], near or just below $1 \%$ in BL/6 bone marrow, spleen and lymph nodes [16], and over 1000-fold less than $\mathrm{V} \kappa 10 \mathrm{~A}$ and $\mathrm{B}$ in BALB/c spleen mRNA [40]. 
Additionally, in naïve adult BALB/c mice, VК10C expression was detected once each from a total of 564 single-sorted follicular and 613 marginal zone B cells $(0.17 \%$ frequency) while $\mathrm{V} \kappa 10 \mathrm{~A}$ and $\mathrm{V} \kappa 10 \mathrm{~B}$ were detected at frequencies of approximately $6 \%$ and $1.6 \%$, respectively (Patel et al., unpublished data).

During the pre-B to immature B cell transition, IgM is expressed on the surface of the developing $B$ cell and productive Vk10C rearrangements are lost [39], which may be a consequence of imbalances in tonic signaling resulting from inefficient $\mathrm{L}$ chain expression or an impaired ability of Vk10C to pair well with $\mathrm{VH}$ chains [48,52,57]. Indeed, at the $\mathrm{VH}$ locus, removal of the $\mathrm{Eu}$ enhancer from one allele is known to result in reduced transcription levels of a rearranged $\mathrm{VH}$ gene on the other allele, such that the surface density of BCR's containing the rearranged VH gene is not sufficient to reach the tonic signaling threshold that is critical for transition of the cells into immature B cells [50]. Vк10C-expressing B cells could also be lost through negative selection, leading to receptor editing to replace the productive $\mathrm{Vk} 10 \mathrm{C}$ rearrangement. To assess the possible reasons for lack of Vk10C usage, we further examined promoter strength, its ability to pair with $\mathrm{V}_{\mathrm{H}}$ chains, and hallmarks of negative selection (receptor editing, RS recombination). Overall, the data support the idea that insufficient BCR expression and tonic signaling resulting from low levels of $\mathrm{V} \kappa 10 \mathrm{C}$ transcription are likely the major reason for loss of productive $\mathrm{V} \kappa 10 \mathrm{C}$ rearrangements in developing $B$ cells, although a very small number survive and migrate to the periphery.

Although our data support the concept of a weak Vк10C promoter, in-silico analyses of the Vk10 promoters by us and others [9] did not reveal differences in transcription factor binding motifs that might explain the weak Vk10 promoter strength. There may be differences in binding of an as yet unknown transcription factor(s) to the $\mathrm{V} \kappa 10$ promoter at site 3 . Although germline $\mathrm{V} \kappa 10 \mathrm{~A}$ and $\mathrm{V} \kappa 10 \mathrm{C}$ transcription rates indicate equal accessibility, subsequent epigenetic modifications to the promoters and the position of the rearranged genes in the contracted locus may influence their interaction with downstream enhancers and affect the rates of transcription.

Using an RNA knockdown approach in-vivo, reduction of Igk transcription in the natural repertoire promotes increased levels of receptor editing whereas cells that maintained normal levels of Igא transcripts and had reduced editing [57]. Conversely, increases in tonic signaling, through enhanced BCR signaling results in suppression of light chain receptor editing [58]. The lack of $\mathrm{V} \kappa 10 \mathrm{C}$ expression is consistent with the idea that inefficient expression of $\mathrm{V} \kappa 10 \mathrm{C}$ in pre-B cells may result in sub-threshold surface expression of BCRs on immature B cells. Insufficient tonic signaling would lead to receptor editing $[48,52,59]$, resulting in the elimination of $\mathrm{V} \kappa 10 \mathrm{C}$ rearrangements due to secondary $\mathrm{L}$ chain recombination.

Productive and non-productive $\mathrm{Vk} 10 \mathrm{C}$ rearrangements associated with secondary JK2 recombination and VkJK-iRS recombination, hallmarks of receptor editing, showed a higher proportion of productive $\mathrm{Vk} 10 \mathrm{C}$ rearrangements associated with these structures. For Vк10C recombinations associated with either structure, the NP/P ratio was $\sim 1$, suggesting that productive $\mathrm{VK}_{\kappa} 10 \mathrm{CJ}$ joints led to subsequent recombination events. For Vк10A and Vк10B in pre-B cells, the NP/P ratio on secondary recombination structures was the expected ratio of $\sim 2$, but in B cells and in $\mathrm{VKJ} \mathrm{J}-\mathrm{iRS}$ structures, the ratio was significantly $<1$, suggesting that between the pre-B cell stage through emigration to the periphery, cells expressing $\mathrm{V} \kappa 10 \mathrm{~A}$ and Vк10B L chains were lost via clonal deletion. These data suggest that there are highly elevated levels of tonic signaling for $\mathrm{VK}_{\kappa} 10 \mathrm{~A}$ and $\mathrm{V \kappa} 10 \mathrm{~B} \mathrm{H}-\mathrm{L}$ chain pairs, but only moderately elevated levels for $\mathrm{V} \kappa 10 \mathrm{C}$ pairs.

Vk10C L chain was not defective in its ability to pair with unique VDJ $\mathrm{H}$ chains and in fact, paired with a wider array of $\mathrm{H}$ chains from both pre- $\mathrm{B}$ cells and splenic $\mathrm{B}$ cells than either $\mathrm{V} \kappa 10 \mathrm{~A}$ or $\mathrm{V \kappa} 10 \mathrm{~B}$. There are qualitative differences between the $V_{\kappa} 10 C-V_{H}$ chain pairs and $V_{\kappa} 10 A$ and $\mathrm{V} \kappa 10 \mathrm{~B}-\mathrm{V}_{\mathrm{H}}$ chain pairs, including more poly-reactivity among $\mathrm{V} \kappa 10 \mathrm{C}-\mathrm{V}_{\mathrm{H}}$ chain pairs (Aydanian et al., manuscript in preparation).

A small number of $\mathrm{B}$ cells that express productive Vk10C rearrangements migrate to the periphery. This successful emigration may be due to specific $V_{\kappa} 10 \mathrm{C}-\mathrm{V}_{\mathrm{H}}$ chain pairs that have appropriate levels of tonic signaling. The majority of these Vk10C-expressing B cells may undergo peripheral selection events leading to further loss of productive rearrangements (Aydanian et al., manuscript in preparation). B cells making a first encounter with a high-affinity auto-antigen in the periphery are deleted at the transition from $\mathrm{T} 1$ to $\mathrm{T} 2$ transitional $\mathrm{B}$ cell stage $[60,61]$ and it is possible that Vk10C-expressing $B$ cells are eliminated here. Another possible fate of Vk10C-expressing cells in the periphery is that they are rendered anergic as a mechanism of silencing self-reactive B cells [62]. Finally, Vк10C-expressing B cells, albeit at very low levels, could become a part of the heterogeneous mature pre-immune repertoire. Studies are in progress to unambiguously identify the route of development for Vk10C-expressing B cells.

\section{Conclusions}

Overall, our findings suggest that the weak promoter of the $\mathrm{V} \kappa 10 \mathrm{C}$ gene acts at the pre-B cell stage to limit the amount of available $\mathrm{V} \kappa 10 \mathrm{C} \mathrm{L}$ chain to generate a $\mathrm{BCR}$. This leads to insufficient BCR expression and tonic signaling, thus triggering receptor editing of productive Vk10C rearrangements. However, limited numbers 
of Vk10C-expressing B cells migrate from the bone marrow to the periphery where additional mechanisms may further reduce Vk10C-expressing B cells as they transition from immature to mature B cells.

\section{Abbreviations}

ACK: Red cell lysis buffer; BCR: B cell receptor; BSA: Bovine serum albumin; CDNA: Complementary DNA; cfu: Colony forming units; Ct: Threshold cycle; DNA: Deoxyribonucleic acid; dNTP: Deoxynucleotide triphosphate; $F_{A B}$ : Antigen-binding fragment of immunoglobulin; FAM: 6carboxyfluorescein; fg: Femtogram; FITC: Fluorescein isothiocyanate; FO: Follicular B cell; mRNA: Messenger RNA; H-chain: Heavy chain of immunoglobulin; Ig: Immunoglobulin; JK: Kappa; kV: Kilovolt; LB: Luria-Bertani; L-chain: Light chain of immunoglobulin; LPS: Lipopolysaccharide; Mb: Megabase; MZ: Marginal zone B cell; ng: Nanogram; NP: Nonproductive Ig rearrangement; NP/P: Nonproductive to productive ratio; P: Productive lg rearrangement; PBS: Phosphate buffered saline; PE: Phycoerythrin; PEG: Polyethylene glycol; qPCR: Quantitative PCR; RNA: Ribonucleic acid; RS: Recombining sequence; RSS: Recombination signal sequence; RT-PCR: Reverse transcription-polymerase chain reaction; TAMRA: Tetramethyl-6-carboxyrhodamine; $\Omega$ : Ohms; $\mu F$ : Micro Faraday; $\mu \mathrm{g}$ : Microgram; $\mu$ l: Microliter; $\mu \mathrm{M}$ : Micromolar; V(D)J: Variable, diversity, and joining; VK: Variable kappa; VL: Variable light chain; VH: Variable heavy chain.

\section{Competing interests}

The authors declare that they have no competing interests.

\section{Authors' contributions}

SF designed and conducted experiments, provided analysis and interpretation of data and drafted the manuscript. AA performed experiments, interpreted data and drafted part of the manuscript. KC performed experiments, acquired and analyzed data. MS designed experiments, interpreted data and critically revised the manuscript for intellectual content. All authors read and approved the final manuscript.

\section{Acknowledgements}

The authors thank Howard Mostowski for pre-B cell sorting and Dr. Mate Tolnay and Dr. Frederick Mills for critical review of this manuscript. This work was supported by the Intramural Research Program of the Center for Drug Research and Review, Food and Drug Administration.

Received: 5 December 2013 Accepted: 17 October 2014

Published online: 30 October 2014

\section{References}

1. Max EE, Maizel JV Jr, Leder P: The nucleotide sequence of a 5.5-kilobase DNA segment containing the mouse kappa immunoglobulin J and C region genes. J Biol Chem 1981, 256(10):5116-5120.

2. Liu ZM, George-Raizen JB, Li S, Meyers KC, Chang MY, Garrard WT: Chromatin structural analyses of the mouse lgkappa gene locus reveal new hypersensitive sites specifying a transcriptional silencer and enhancer. J Biol Chem 2002, 277(36):32640-32649.

3. Picard D, Schaffner W: A lymphocyte-specific enhancer in the mouse immunoglobulin kappa gene. Nature 1984, 307(5946):80-82.

4. Queen C, Baltimore D: Immunoglobulin gene transcription is activated by downstream sequence elements. Cell 1983, 33(3):741-748.

5. Queen C, Stafford J: Fine mapping of an immunoglobulin gene activator. Mol Cell Biol 1984, 4(6):1042-1049.

6. Meyer KB, Neuberger MS: The immunoglobulin kappa locus contains a second, stronger B-cell-specific enhancer which is located downstream of the constant region. EMBO J 1989, 8(7):1959-1964.

7. Schable KF, Thiebe R, Bensch A, Brensing-Kuppers J, Heim V, Kirschbaum T, Lamm R, Ohnrich M, Pourrajabi S, Roschenthaler F, Schwendinger J, Wichelhaus D, Zocher I, Zachau HG: Characteristics of the immunoglobulin Vkappa genes, pseudogenes, relics and orphons in the mouse genome. Eur J Immunol 1999, 29(7):2082-2086.

8. Thiebe R, Schable KF, Bensch A, Brensing-Kuppers J, Heim V, Kirschbaum T, Mitlohner H, Ohnrich M, Pourrajabi S, Roschenthaler F, Schwendinger J, Wichelhaus D, Zocher I, Zachau HG: The variable genes and gene families of the mouse immunoglobulin kappa locus. Eur J Immunol 1999 29(7):2072-2081.

9. Brekke KM, Garrard WT: Assembly and analysis of the mouse immunoglobulin kappa gene sequence. Immunogenetics 2004 56(7):490-505.

10. Kaushik A, Schulze DH, Bona C, Kelsoe G: Murine V kappa gene expression does not follow the VH paradigm. J Exp Med 1989, 169(5):1859-1864.

11. Teale JM, Morris EG: Comparison of $V$ kappa gene family expression in adult and fetal B cells. J Immunol 1989, 143(8):2768-2772.

12. Lawler AM, Kearney JF, Kuehl M, Gearhart PJ: Early rearrangements of genes encoding murine immunoglobulin kappa chains, unlike genes encoding heavy chains, use variable gene segments dispersed throughout the locus. Proc Natl Acad Sci U S A 1989, 86(17):6744-6747.

13. Ramsden DA, Paige CJ, Wu GE: Kappa light chain rearrangement in mouse fetal liver. J Immunol 1994, 153(3):1150-1160.

14. Li S, Garrard WT: The kinetics of V-J joining throughout 3.5 megabases of the mouse Ig kappa locus fit a constrained diffusion model of nuclear organization. FEBS Lett 2003, 536(1-3):125-129.

15. Kalled SL, Brodeur PH: Utilization of V kappa families and V kappa exons. Implications for the available B cell repertoire. J Immunol 1991, 147(9):3194-3200.

16. Aoki-Ota M, Torkamani A, Ota T, Schork N, Nemazee D: Skewed primary Igkappa repertoire and V-J joining in C57BL/6 mice: implications for recombination accessibility and receptor editing. J Immunol 2012, 188(5):2305-2315

17. Goldmit M, Ji Y, Skok J, Roldan E, Jung S, Cedar H, Bergman Y: Epigenetic ontogeny of the lgk locus during B cell development. Nat Immunol 2005, 6(2):198-203.

18. Kosak ST, Skok JA, Medina KL, Riblet R, Le Beau MM, Fisher AG, Singh H: Subnuclear compartmentalization of immunoglobulin loci during lymphocyte development. Science 2002, 296(5565):158-162.

19. Roldan E, Fuxa M, Chong W, Martinez D, Novatchkova M, Busslinger M, Skok JA: Locus 'decontraction' and centromeric recruitment contribute to allelic exclusion of the immunoglobulin heavy-chain gene. Nat Immunol 2005, 6(1):31-41.

20. Schatz DG, Ji Y: Recombination centres and the orchestration of V(D)J recombination. Nat Rev Immunol 2011, 11(4):251-263.

21. Sleckman BP, Gorman JR, Alt FW: Accessibility control of antigen-receptor variable-region gene assembly: role of cis-acting elements. Annu Rev Immunol 1996, 14:459-481.

22. Fitzsimmons SP, Bernstein RM, Max EE, Skok JA, Shapiro MA: Dynamic changes in accessibility, nuclear positioning, recombination, and transcription at the Ig kappa locus. J Immunol 2007, 179(8):5264-5273.

23. Bevington S, Boyes J: Transcription-coupled eviction of histones $\mathrm{H} 2 \mathrm{~A} / \mathrm{H} 2 \mathrm{~B}$ governs V(D)J recombination. EMBO J 2013, 32(10):1381-1392.

24. McMurry MT, Krangel MS: A role for histone acetylation in the developmental regulation of VDJ recombination. Science 2000, 287(5452):495-498.

25. Perkins EJ, Kee BL, Ramsden DA: Histone 3 lysine 4 methylation during the pre-B to immature B-cell transition. Nucleic Acids Res 2004, 32(6):1942-1947.

26. Johnson K, Angelin-Duclos C, Park S, Calame KL: Changes in histone acetylation are associated with differences in accessibility of $\mathrm{V}(\mathrm{H})$ gene segments to V-DJ recombination during B-cell ontogeny and development. Mol Cell Biol 2003, 23(7):2438-2450.

27. Espinoza CR, Feeney AJ: The extent of histone acetylation correlates with the differential rearrangement frequency of individual $\mathrm{VH}$ genes in pro- $\mathrm{B}$ cells. J Immunol 2005, 175(10):6668-6675.

28. Agata Y, Katakai T, Ye SK, Sugai M, Gonda H, Honjo T, Ikuta K, Shimizu A: Histone acetylation determines the developmentally regulated accessibility for $\mathrm{T}$ cell receptor gamma gene recombination. J Exp Med 2001, 193(7):873-880.

29. McBlane F, Boyes J: Stimulation of $V(D) J$ recombination by histone acetylation. Curr Biol 2000, 10(8):483-486.

30. Hesse JE, Lieber MR, Mizuuchi K, Gellert M: V(D)J recombination: a functional definition of the joining signals. Genes Dev 1989, 3(7):1053-1061.

31. Ramsden DA, Baetz K, Wu GE: Conservation of sequence in recombination signal sequence spacers. Nucleic Acids Res 1994, 22(10):1785-1796.

32. Nadel B, Tang A, Lugo G, Love V, Escuro G, Feeney AJ: Decreased frequency of rearrangement due to the synergistic effect of nucleotide 
changes in the heptamer and nonamer of the recombination signal sequence of the $V$ kappa gene $A 2 b$, which is associated with increased susceptibility of Navajos to Haemophilus influenzae type b disease. J Immunol 1998, 161(11):6068-6073.

33. Buchanan KL, Smith EA, Dou S, Corcoran LM, Webb CF: Family-specific differences in transcription efficiency of Ig heavy chain promoters. $\mathrm{J}$ Immunol 1997, 159(3):1247-1254.

34. Stiernholm BJ, Berinstein NL: Mutations in immunoglobulin V gene promoters may cause reduced germline transcription and diminished recombination frequencies. Ann N Y Acad Sci 1995, 764:116-120.

35. Stiernholm NB, Berinstein NL: A mutated promoter of a human Ig V lambda gene segment is associated with reduced germ-line transcription and a low frequency of rearrangement. J Immunol 1995, 154(4):1748-1761.

36. Casellas R, Shih TA, Kleinewietfeld M, Rakonjac J, Nemazee D, Rajewsky K, Nussenzweig MC: Contribution of receptor editing to the antibody repertoire. Science 2001, 291(5508):1541-1544.

37. ten Boekel $E$, Melchers F, Rolink AG: Changes in the $V(H)$ gene repertoire of developing precursor $B$ lymphocytes in mouse bone marrow mediated by the pre-B cell receptor. Immunity 1997, 7(3):357-368.

38. Jayaram N, Bhowmick P, Martin AC: Germline VH/VL pairing in antibodies. Protein Eng Des Sel 2012, 25(10):523-529.

39. Fitzsimmons SP, Clark KJ, Mostowski HS, Shapiro MA: Underutilization of the $V$ kappa $10 \mathrm{C}$ gene in the $B$ cell repertoire is due to the loss of productive VJ rearrangements during B cell development. J Immunol 2000, 165(2):852-859.

40. Fitzsimmons SP, Rotz BT, Shapiro MA: Asymmetric contribution to lg repertoire diversity by $\mathrm{V}$ kappa exons: differences in the utilization of $\mathrm{V}$ kappa 10 exons. J Immunol 1998, 161(5):2290-2300.

41. de Haard HJ, van Neer N, Reurs A, Hufton SE, Roovers RC, Henderikx P, de Bruine AP, Arends JW, Hoogenboom HR: A large non-immunized human Fab fragment phage library that permits rapid isolation and kinetic analysis of high affinity antibodies. J Biol Chem 1999, 274(26):18218-18230.

42. Amersdorfer P, Wong C, Chen S, Smith T, Deshpande S, Sheridan R, Finnern R, Marks JD: Molecular characterization of murine humoral immune response to botulinum neurotoxin type $A$ binding domain as assessed by using phage antibody libraries. Infect Immun 1997, 65(9):3743-3752.

43. Retter MW, Nemazee D: Receptor editing occurs frequently during normal B cell development. J Exp Med 1998, 188(7):1231-1238.

44. Ye J, Ma N, Madden TL, Ostell JM: IgBLAST: an immunoglobulin variable domain sequence analysis tool. Nucleic Acids Res 2013, 41(Web Server issue):W34-W40

45. Retter I, Chevillard C, Scharfe M, Conrad A, Hafner M, Im TH, Ludewig M, Nordsiek G, Severitt S, Thies S, Mauhar A, Blocker H, Muller W, Riblet R: Sequence and characterization of the lg heavy chain constant and partial variable region of the mouse strain 129S1. J Immunol 2007, 179(4):2419-2427.

46. Shapiro MA, Weigert M: How immunoglobulin V kappa genes rearrange. J Immunol 1987, 139(11):3834-3839.

47. Lu L, Osmond DG: Apoptosis during B lymphopoiesis in mouse bone marrow. J Immunol 1997, 158(11):5136-5145.

48. Keren Z, Diamant E, Ostrovsky O, Bengal E, Melamed D: Modification of ligand-independent $B$ cell receptor tonic signals activates receptor editing in immature B lymphocytes. J Biol Chem 2004, 279(14):13418-13424.

49. Monroe JG: ITAM-mediated tonic signalling through pre-BCR and BCR complexes. Nat Rev Immunol 2006, 6(4):283-294.

50. Peng $C$, Eckhardt LA: Role of the Igh intronic enhancer Emu in clonal selection at the pre-B to immature B cell transition. J Immuno/ 2013, 191(8):4399-4411.

51. Rowland SL, DePersis CL, Torres RM, Pelanda R: Ras activation of Erk restores impaired tonic $B C R$ signaling and rescues immature $B$ cell differentiation. J Exp Med 2010, 207(3):607-621.

52. Tze LE, Schram BR, Lam KP, Hogquist KA, Hippen KL, Liu J, Shinton SA, Otipoby KL, Rodine PR, Vegoe AL, Kraus M, Hardy RR, Schlissel MS, Rajewsky K, Behrens TW: Basal immunoglobulin signaling actively maintains developmental stage in immature B cells. PLoS Biol 2005, 3(3):e82.

53. Sanchez $P$, Crain-Denoyelle AM, Daras P, Gendron MC, Kanellopoulos-Langevin C: The level of expression of mu heavy chain modifies the composition of peripheral B cell subpopulations. Int Immunol 2000, 12(10):1459-1466.
54. Heltemes LM, Manser T: Level of B cell antigen receptor surface expression influences both positive and negative selection of $B$ cells during primary development. J Immunol 2002, 169(3):1283-1292.

55. Casola S, Otipoby KL, Alimzhanov M, Humme S, Uyttersprot N, Kutok JL, Carroll MC, Rajewsky K: B cell receptor signal strength determines B cell fate. Nat Immunol 2004, 5(3):317-327.

56. Xing Y, Li W, Lin Y, Fu M, Li CX, Zhang P, Liang L, Wang G, Gao TW, Han H, Liu YF: The influence of BCR density on the differentiation of natural poly-reactive $B$ cells begins at an early stage of $B$ cell development. Mol Immunol 2009, 46(6):1120-1128.

57. Shen $\mathrm{S}$, Manser T: Direct reduction of antigen receptor expression in polyclonal B cell populations developing in vivo results in light chain receptor editing. J Immunol 2012, 188(1):47-56.

58. Ramsey LB, Vegoe AL, Miller AT, Cooke MP, Farrar MA: Tonic BCR signaling represses receptor editing via Raf- and calcium-dependent signaling pathways. Immunol Lett 2011, 135(1-2):74-77.

59. Schram BR, Tze LE, Ramsey LB, Liu J, Najera L, Vegoe AL, Hardy RR, Hippen KL, Farrar MA, Behrens TW: B cell receptor basal signaling regulates antigen-induced Ig light chain rearrangements. $J$ Immunol 2008, 180(7):4728-4741.

60. Ait-Azzouzene D, Gavin AL, Skog P, Duong B, Nemazee D: Effect of cell:cell competition and BAFF expression on peripheral B cell tolerance and B-1 cell survival in transgenic mice expressing a low level of Igkappa-reactive macroself antigen. Eur J Immunol 2006, 36(4):985-996.

61. Ota T, Ota M, Duong BH, Gavin AL, Nemazee D: Liver-expressed Igkappa superantigen induces tolerance of polyclonal B cells by clonal deletion not kappa to lambda receptor editing. J Exp Med 2011, 208(3):617-629.

62. Merrell KT, Benschop RJ, Gauld SB, Aviszus K, Decote-Ricardo D, Wysocki LJ, Cambier JC: Identification of anergic B cells within a wild-type repertoire. Immunity 2006, 25(6):953-962.

doi:10.1186/s12865-014-0051-2

Cite this article as: Fitzsimmons et al:: Multiple factors influence the contribution of individual immunoglobulin light chain genes to the naïve antibody repertoire. BMC Immunology 2014 15:51.

\section{Submit your next manuscript to BioMed Central and take full advantage of:}

- Convenient online submission

- Thorough peer review

- No space constraints or color figure charges

- Immediate publication on acceptance

- Inclusion in PubMed, CAS, Scopus and Google Scholar

- Research which is freely available for redistribution 